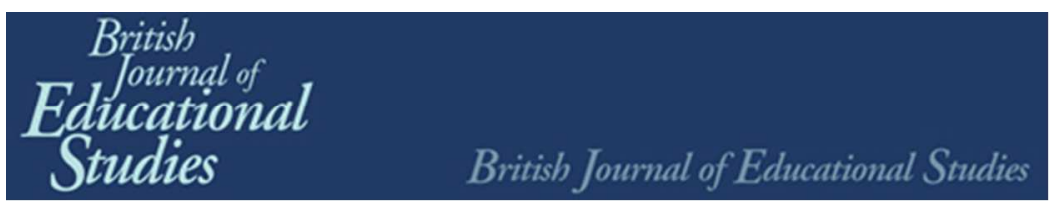

\title{
Belonging, Social Cohesion and Fundamental British Values
}

\begin{tabular}{|c|c|}
\hline Journal: & British Journal of Educational Studies \\
\hline Manuscript ID & BJES-11-17-0129-RI.R3 \\
\hline Manuscript Type: & Original Article - Regular Issue \\
\hline Keywords: & $\begin{array}{l}\text { Fundamental British Values, social cohesion, belonging together, perceived } \\
\text { belonging, promotion policies }\end{array}$ \\
\hline Abstract: & $\begin{array}{l}\text { Many of the often complex debates central to the topics of belonging and } \\
\text { social cohesion have their origins in contrasting interpretations of the ideal } \\
\text { relationship between citizens. Governments across much of the western } \\
\text { world continue to struggle to reconceptualise what it is to 'belong together' } \\
\text { at a time of growing diversity and migration. } \\
\text { This article considers three conceptual difficulties involved in the directive } \\
\text { for schools to actively promote Fundamental British Values to address this } \\
\text { issue. First, the directive fails to refer to any relevant theories around the } \\
\text { concept of belonging, one of the major strands of research in social } \\
\text { cohesion. The concept of 'perceived belonging' is thus introduced to further } \\
\text { explore what the bond between citizens 'looks like'. Secondly, the lack of } \\
\text { theory leads to a restriction of the values needed to support the bond. } \\
\text { Thirdly, there is then a lack of sufficient clarity of action for how this might } \\
\text { be translated into school practice. Finally, I suggest that the directive } \\
\text { needs further theoretical engagement to be successful. }\end{array}$ \\
\hline
\end{tabular}




\section{BELONGING, SOCIAL COHESION AND FUNDAMENTAL BRITISH VALUES}

\section{INTRODUCTION}

Much discussion in political and social philosophy over the past two decades has centred on the widespread beliefs that modern, diverse societies are currently failing to engender sufficient cohesion (both community and societal) to counter the connected problems of social disorder, alienation, terrorism and fragmentation of belonging. These difficulties have their roots in many common political issues across much of the western world: multiculturalism and integration of minorities; the balance between the rights of individuals and communities; worries about radicalisation or terrorism; the growth of independence movements and the re-emergence of far-right political parties across the world. ${ }^{1}$ Faced by such predicaments, governmental policy agendas struggle to reconceptualise national identity, in the sense of what it is to 'belong together' at a time of growing diversity and migration.

These problems have come to influence policy making across Europe, as well as in the UK, where successive governments have attempted to promote cohesion and integration (for example Hooghe 1996, Cantle 2001, Buonfino and Thomson 2007, DCSF 2007 Bachtler and Mendez 2016). In response to terrorism and radicalisation anxieties within the UK (including concerns emanating from the 'Trojan horse' schools in Birmingham), the former UK Prime Minister, David Cameron, announced a new policy of the active promotion of 'fundamental British values' (FBV) in schools. ${ }^{2}$ This came to be defined as 'the fundamental British values of democracy, the rule of law, individual liberty and mutual respect and tolerance of those with different faiths and beliefs' (DfE Nov 2014: 5). He justified the 
creation of this policy by claiming that some form of value consensus was needed to unite us and build a 'common home' ${ }^{3}$ If these values prove to be able to do this, they could potentially play a crucial role in achieving important forms of social cohesion.

Whilst this paper focuses on a policy in the context of English liberal democracy (education being one of the areas devolved to the regional parliaments), it has a wider application by addressing issues relevant to the state education of citizens elsewhere. Many of the debates emanating from this policy can be linked to ongoing discussions in philosophical thinking: loyalty and loyalties; solidarity and belonging; the structure and content of human values; the role of schools in creating citizens. Nevertheless, the inherent theoretical problems arising from this directive call into question the possibility of it achieving its stated goals, demonstrating an urgent need for further significant philosophical work.

Starting from an outline of the policy in question and the need for social cohesion, I then move into the main claims to be addressed in this paper: that there are no good reasons to believe that this directive can create a deep sense of social cohesion for three reasons. I then consider the first of these: that the directive has an inadequate concept of belonging, a focus of one the major strands of research in social cohesion. I suggest the addition of 'perceived belonging' needed for an adequate understanding of social cohesion. After this, I turn to the second of the three reasons: that the current lack of attention to the concept being used then leads to a misunderstanding of the precise content (the values) needed to support social cohesion. Next, I address the third reason: that the method of enactment (actively promoting) lacks sufficient clarity about action with a corresponding ambiguity as to how this might be translated into school practice. Finally, I argue that to reach the desired end-goal of social cohesion requires more philosophical attention to be paid to the way in which citizens might belong together. 


\section{CREATING CITIZENRY: THE DIRECTIVE}

Many of the often complex debates central to the topic of social cohesion have their origins in contrasting interpretations of the fundamental commitments and traditions to be found in conceptualisations of the ideal relationship between citizens (Leydet 2006, Honohan 2008, Mokrosinska 2012). Whilst not all debates, admittedly, are purely philosophical, the modelling of the relationship between citizens and the state and how this may be sustained through the generations has a long history in philosophical writing around what holds society together, what provides unity and how diverse persons can live together. The precise value of social cohesion, when positioned as a goal for education, is then based on the need to build a nation in which all groups are both included and to which they feel attached, enabling them to act as one and/or to create a common future together (Healy 2013). In other words, social cohesion creates a model for how to think about belonging at a macro level (Dobbernack 2010).

The need to belong is thought to have an evolutionary basis: when some are in groups, it makes sense for survival purposes to belong to a group oneself - particularly one comprising of familiar, cooperative people. An unspoken "internal mechanism" orientates a sense of belonging and marks the commitment to support those "like us" in significant ways (Baumeister and Leary 1995). Some theorists attest that this can be achieved via some form of shared national identity. In many such arguments, this is needed as a prerequisite to create the background for stability, support for toleration or a shared sense of 'the common good' needed to shape the social world (for example Barry 1983, Miller 1998). Discourses in favour of 'British Values' could then be understood as a form of political 'rallying cry': that those who share the same values will be loyal to the source of these values and refrain from extremism, violence and disloyalty. Needless to say, others claim that a purely civic identity, based on the relationship between diverse citizens is more appropriate. Theorists in this camp 
worry that deliberately fostering political loyalty (as in patriotism) may act to stifle judgement over the worth of the loyalty-object (in this case, the patria), thus becoming 'uncritical attachments' (Nussbaum 1996, Osler 2009, Hand 2011, Keller 2015). Philosophers such as Michael Merry try to find a half-way point between the two stances, indicating that one of the key responsibilities of citizens in a democracy is that they should be able to hold their governments to account - ruling out completely 'uncritical attachments', but accepting a legitimate form of patriotic education: ‘critical patriotism' (Merry 2009).

Traditionally, state-provided schools have played a major role in creating citizens in western societies, not least by transmitting basic norms through the generations. This has historically been the case whether or not a society aligns itself with some form of democracy. For the purposes of this paper, it may then be initially tempting to interpret the policy in question, Fundamental British Values (FBV), as just another articulation of such forms of citizenship education, yet there are distinct differences.

The phrase itself, 'Fundamental British Values' (FBV), achieved public prominence in a security approach from 2011, commonly known as the Prevent strategy, aimed at prevention of extremism and radicalisation before entering educational discourses (DfE 2014, DfE 2015, DfE Nov 2014). ${ }^{4}$ In this domain, radicalisation is usually understood as a process by which an individual (or a group) adopts extreme stances that may entail rejecting the status quo, whether it be political, religious or social (Wilner and Dubouloz 2010). Extremism pushes this further still, depicting stances far outside of majority thinking that may prevent compromise or exclude other perspectives (Kundnani 2012, Arthur 2015). It is rarely a selfchosen label and often used in reference to those who advocate some form of violence.

Nevertheless, it cannot automatically be assumed that adopting a radical stance to currently accepted ideas is 'dangerous': many may adopt such a stance without going on to 
engage in any form of terrorist activity at all (Sieckelinck, Kaulingfreks et al. 2015). Indeed, opposition to, or dissent from, any part of the Fundamental British Values is now considered the very definition of extremism: "Extremism" is defined in the 2011 Prevent strategy as vocal or active opposition to fundamental British values...' (HM Government 2015: 20). But classifying some act or thought as 'extremist' in these terms may be seen by some as suppressing legitimate critique or as justifying arguments that the aim of the policy is indeed to create the 'uncritical attachments' often associated with patriotic education. This becomes particularly complex for educators required to patrol such issues in that, as Sieckelinck et al (2015) points out, the role of teachers is to educate their students and not to see them as automatically suspect, dangerous or targets for surveillance as might security forces.

The justification for this change in educational policy (from previous discourses of 'shared' or 'common values' in citizenship education) was given as being necessary to prepare pupils for life in modern Britain. The values in question (originally named in the Prevent strategy) were formally listed in educational documents as: 'democracy, the rule of law, individual liberty and mutual respect and tolerance of those with different faiths and beliefs and for those without faith' (Ofsted 2015: 38). Besides the removal of the phrase 'and for those without faith' in subsequent documents, there has been no further official clarification, save recent reported comments from Ofsted that schools should do more to prevent terrorism by 'properly promoting British values'.

Unlike many other 'promoting' policies, FBV was designed to be deeply embedded into other educational policies and more general school policies. In other words, it is not a 'stand alone' educational policy, but a reinforcement of existing requirements found in other legislation. Schools were advised that this new duty came with the expectation that FBV would permeate the ethos, relationships and relevant activities beyond the classroom, as well as having a place in the curriculum. Further directives were released on how this might be 
done through SMSC (social, moral, spiritual and cultural curricula) (DfE 2014, DfE 2015a) or linked to the Prevent strategy (DfE 2015b).

To date, much of the critique of this directive has focussed on the concept of 'Britishness', the securitisation for the state or exploring teachers' practices (for example Arthur 2015, Richardson 2015, Lander 2016, Panjwani 2016, Smith 2016). Four areas attract attention in this expanding literature. First, teachers' individual responsibility: the requirement is now that all teachers should 'not undermine' fundamental British values (DfE 2012) - but it is not spelled out what exactly counts as undermining (Lander 2016). As this is a requirement for all teachers, and not just subject specialists in citizenship, PSHE, history, RE etc, teachers need to know more fully what it is they are required to do in the classroom but equally what they should not be doing. Secondly, the content (including the learning activities, particularly through SMSC: there has been little to no reference made to citizenship education as a distinct subject, which had previously covered many of the activities cited as contributing to FBV: how democracy and the law works etc. Thirdly, new legal responsibilities: making school leaders (head teachers and governors) responsible for ensuring the school as a whole upholds FBV. They are now required, as part of their professional duty, to actively promote fundamental British values, to protect and safeguard children from radicalisation and extremism and the success of this will be reported on through Ofsted inspections (Ofsted 2015), yet with little clarity as to the precise boundaries of these terms. Fourthly, through oversight arrangements (inspection frameworks overseen by Ofsted): schools can now be given a fail grade for failure to promote fundamental British values (Ofsted 2015). This would then give grounds for governmental intervention on the grounds of 'safe-guarding children' and indeed several schools have been failed in such a way. ${ }^{6}$ 
Much of the deliberation in policy comes from attempts to determine what should be done and whether these principles provide a feasible standard for practice. Admittedly, ideal models are not always easily articulated and realized at the level of policy and pedagogy - but theory plays a crucial role by helping to delineate those policies that accord with existing values, and to exclude those contrary to them. Given the critical importance of this directive for practice, further analysis of theory relevant to this area is urgently needed to make sense of this directive, starting with what the bond between citizens 'looks like'.

\section{FRAMING THE DISCUSSION: BELONGING TOGETHER}

Whilst the nation-state (based on a $19^{\text {th }}$ Century construction of a single nation/culture) has been credited with providing the sense of national-identity required to engender a sense of belonging to the body politic, this view has long been under attack from competing perspectives. Social and political geographers have repeatedly pointed out that being a member of the state no longer implies being a member of the nation (for example Antonsich 2009), hence previously held national, ethnic or cultural definitions that might have been called on in times past to achieve this task then become subject to revision. In other words, 'the normal transmission of national identity from generation to generation has been thrown into crisis' (Kundnani 2012: 163).

A more nuanced understanding of political belonging has emerged in recent decades, often crossing disciplines, whereby the concept embraces a much wider understanding of the possibility of multiple belongings (Christiansen and Hedetoft 2004, Clark 2009, Antonsich 2010, Vasta 2013). Within the vast literature, two particular strands are commonly identified: belonging can be understood as 'membership belonging' (articulated through the language of rights and responsibilities) and 'a sense of belonging' (Yuval-Davis 2006, Antonsich 2010, 
Guibernau 2013). In this commonly made distinction, the former is used to refer to the more official public structures often associated with membership, citizenship or formal belonging: rights of entry/abode; passports/identity cards; access to welfare rights or state services. The latter then refers to more personal attachments to place, communities or practices often associated with emotional connections found in personal everyday activities: for example a feeling of being 'at home'; the emotional dimension of status; a sense of rootedness. But this articulation of belonging is not without its problems: it is possible to have legal or formal belonging and yet to lack a feeling of belonging to that community (the problem of marginalised communities). Similarly, one can feel a sense of belonging to a place or community and yet lack membership rights to be there (the problem of the undocumented).

There is, however, a more fundamental problem: whilst belonging is commonly used as a verb, it also functions in terms of an ascribed status. This suggests a third possible component of belonging: 'perceived belonging'. A person may have full membership belonging and have a highly developed sense of belonging to a community and yet the established community may not accept them as belonging there. Hence someone could acquire full membership legal rights and feel a deep sense of belonging (whether to a place or to a community) and yet be rejected by others in the wider established group as not having a 'moral' right to the shared goods of the community. ${ }^{7}$

This notion of perceived belonging can be developed by thinking further about how people belong: belonging-to something is very different from belonging-with something and this difference plays a not inconsiderable part when starting to conceptualise forms of social cohesion. Whilst both belongings hold identity-forming expectations, belonging-to emphasises membership (e.g. I belong to the reading group); belonging-with, on the other hand, emphasises commitment. This more horizontal bond commits oneself to stand alongside of particular others, joined in some form of shared destiny. It is the belonging-with 
that leads to forms of social cohesion. This discourse is often referenced as belonging together. This sense of belonging together, forming a citizenry, needs to draw on an emotional attachment deep and strong enough to uphold some form of a shared identity, loyalty and solidarity that is capable of motivating collective mobilisation when needed (sometimes referred to as fraternity) (Healy 2013). Belonging in groups requires both membership and a sense of belonging, but to achieve cohesion, also requires perceived belonging: all parties (the state, the individual and the collective citizenry) need to see each other as legitimately belonging together. What counts as 'legitimate' is a complex question that is inherently context sensitive, and this can only be determined by rules known, understood and acceptable to all involved.

\section{PERCEIVED BELONGING}

This concept of 'perceived belonging' attempts to draw into the discourses of belonging the voices beyond those provided by membership (in this case granted by the state) or a sense of belonging (felt by individuals), emphasising that belonging is at heart relational: it is about the self with others. As with many new concepts, it draws on other similar concepts as interlocking systems of concepts that form a framework for reasoning about shared commitments; in this case, it draws on familiar concepts such as recognition and solidarity. In what follows, I highlight the layers of relevant relational issues associated with this view of personhood.

In one form or another, recognition has emerged as a key concept in recent decades, not only in philosophy but also in social theory, 'identity politics' and the 'politics of difference' (Probyn 1996, Yuval-Davis, Anthias et al. 2005, Jayaweera and Choudhary 2008, Antonsich 2010). A number of social movements call for a greater emphasis and acknowledgement of different 'voices' in discourses of inclusion and exclusion including the 
willingness to grant social recognition. Social recognition grants group members a status of holding and exercising entitlements granted by the group, thus anchoring them in their selfidentity.

In much of the existing literature on recognition, the focus is on the way in which the self becomes recognised: those who are recognised as belonging, are then accredited a social identity. The self, in this argument, is striving to become an ' $\mathrm{I}$ ' or subject against a background from which her personhood arose, to evaluate and seek esteem as an individual. Here the self attempts to delineate that which is 'I' from others (they/them). This then suggests that when a person 'asks' for recognition, part of what is being asked for is confirmation of what she believes herself to be.

Whilst I might come up with an account of who I believe myself to be, I also need an account that describes how I might be seen (or perceived) by others. Others may see me in very different ways: they may have a very different opinion of me as a social being (which could add to the self-knowledge I may already have about myself). I not only need to see myself, but I also need to be seen by others, as a full member of the group, holding and exercising entitlements granted by the group to its members. This gives perceived belonging a dialogic role: I partially become conscious of who I am through the images others have of me and that I have of them.

As Charles Taylor suggests, our core identity is not determined alone but in company and in activity with others (Taylor 1989). The concept of perceived belonging serves to remind us that who I am is at least partly social, and as such, is formed by how 'I' am defined by those around me. But it goes beyond this to position membership in a group to be, at least in part, a matter of mutual recognition: as something that is done with others. All parties bring together their individual understandings and experiences, interacting and influencing each 
other, constantly changing and adapting in response to the image significant others may have. Such mutual recognition only works by seeing and treating others as 'one of us': going from recogniser to recognised - 'I recognise you' and 'you recognise me' and it is only when this mutual recognition is achieved, that discussion of the 'we' needed for cohesion becomes possible. This mutuality evolves over time between members of the group as acknowledged and understood parties, who may then be taken into account in policy formation or revision. ${ }^{8}$ It is important to note that to achieve the 'We-ness' of cohesion does not require adopting a deep shared identity: only that each party must willingly accept the other as a fellow citizen concerned with the pursuit of at least some common ends achieved through living together. Moving from the first person singular (I) to a position of first person plural (we) places the self with others. The individual then becomes a member of a group that can act as one - not by the individual losing their own identity, nor subsuming it within that of another - but by committing to treat others as belonging with us for particular purposes.

Looking at this problem from a different angle: without a commitment to treat another as belonging with us, recognition becomes positioned purely as something that is given to us, suggesting that individuals are mere spectators in their own lives, as opposed to agents-whocan-act. In such circumstances, individuals have not been included in the reflective appraisal involved but have been presented with an account as defined by others which may, or may not be accurate. Instead of being the active creator of a social identity, individuals then become the passive receiver of another's vision.

Similarly, when recognition is given, the range of available options for who-I-mightbe can result in some identities becoming contested or a source of conflict. Take, for example, the wearing of overt religious symbols in France, which have been banned in schools, universities or government buildings. Gereluk argues that some forms of clothing are more than just an expression of one's individuality and can be a constitutive part of one's 
identity (Gereluk 2008). Refusing children the right to wear particular clothing that is an outward sign of their faith commitments, arguably compromises their identity; to be accepted, or to remain in school, then requires them to fragment their identity in some way. In extreme circumstances, such an imbalance between the 'permitted' given options and the self-chosen identity might even demand one moves to the other's position in public out of fear, or even to resituate one's own existing ontological landscape, to prevent existing 'recognition' from being withdrawn.

Just as problematic as recognition being given is to have it withheld or denied. To be denied recognition as a legitimate party can injure our pride, our status and deny us a social identity; we can be humiliated, injured and disenfranchised by being publicly positioned as 'outsiders'. In such circumstances, the 'we' that is constructed reminds us from the start that we are perceived as neither 'welcome' nor 'at home'.

Whilst the ideal is to be accepted and taken into account in our efforts to become an active creator of our social identity, the reality is that power or control of the discourses by particular players (usually the state or fellow citizens) inevitably influences these metaphoric 'conversations'. Because any discourse over shared values and understandings of who 'we' are is often the result of struggles over membership to begin with, debates can reflect or reinforce power structures in a society and thus serve the interests of those who hold most power (Honneth and Margalit 2001, May 2011). This means that not all may be 'equal speakers' in this venture right from the start; some may be seen as outside of the community, 'not one of us' and thus in need of 'special attention': some voices may be limited, or distorted in practice; some are kept silent or ignored - thus the ability to negotiate or 'become' a speaker and to be heard and accepted may itself be restricted.

This affects some more that others and marginalised groups in particular often lack power to negotiate on equal terms or lack adequate access to the communal conditions 
affecting the capacity to exercise such agency. In such situations, seeing one's public persona to be found wanting (or to be transformed) without being part of the process can be both upsetting and alienating. In the context of this policy directive (FBV), this has left some to feel that the default position indeed questions their status, belonging and loyalty (perceives them as 'other' or 'outsiders'), thus misrecognising them (Richardson 2015). This is particularly problematic in the context of schools, increasing the possibility that conversations or discussions could be 'shut down' or avoided by pupils for fear of being misunderstood or reported to authorities; staff themselves might become reluctant to engage with controversial topics - and early reports seem to suggest that this is precisely what has happened in some schools (Press Association 2015, Busher, Choudhury et al. 2017). If social cohesion is indeed an aim of this policy, then is it appropriate that educational establishments should intimate that some groups of pupils do not quite belong or are 'suspect' in some way?

But why does it matter how the bond between citizens is theorised? Is it just a matter of semantics, or is there more at stake? I want to suggest two reasons which I will address in the remainder of the paper. First, theory helps us to identify the coherence of values between the desired goal and wider value structures in society, making application more likely to be successful. Secondly, having a clear view of the bond being aimed at is more likely to be translated into successful school practice.

\section{THE CONTENT: FUNDAMENTAL BRITISH VALUES}

At the heart of this, is a familiar philosophical problem: how is an account of public values created that is 'thick' enough to sustain the communal demands of citizenship yet 'thin' enough to satisfy liberal demands that individuals should be free to choose their own conceptions of the good midst legitimate diversity. Given this familiar background, many states have attempted to redefine values, taking greater account of national context and 
particularity in a move away from previous universalist value frameworks (Lentin 2014). These national values, clearly understood and broadly shared by all, are then offered as the desired binding thread between the citizens.

Nevertheless, previous attempts to align values with a particular state tend to run into similar difficulties: first, national values systems inevitably end up privileging the value systems of a particular nation or geographical/cultural body thus the values of the dominant group will inevitably take precedence. The diversity and ethno-cultural plurality found in most western liberal democracies can then unintentionally lead to some groups being subject to 'the problem of persistent minorities' or to be marginalised. Secondly, national values can politicise the values: the state is then made the ultimate source of these values and has control over the content and interpretation, having the effect of making the values the servant of the state. This can result in a truncated account of the value itself, making it inconsistent with more global interpretations thus restricting its broad reach within a population. Thirdly, national values frameworks can become highly controversial when seen against particular historical backgrounds (for example, in Northern Ireland or Catalonia, where identity divisions are complicated, divided and complex): in short - national values in such cases can often divide rather than unite.

So how might this directive be understood against these common pitfalls? Given that the values in question in the FBV directive have been labelled as specifically fundamental, this makes a good place to start. First, by calling these values 'fundamental', the implication is that they are basic to something, fulfil a particular role in collective lives and, in this case, provide the basic principles dictating what is considered acceptable conduct for all members of the group. They might be held to be core and essential to the belief system embraced or deemed the most important part on which other parts depend or can be built. Secondly, the values in question are labelled as British values and it is this element that has attracted most 
public attention, with many decrying the 'annexation' of the values for seemingly political purposes. Others have objected to the implications that some faith communities were portrayed as being opposed to British values, leading to images of the secular West juxtaposed against the religious East (as argued by Arthur, 2015: 322). So already, the directive seems to be running into familiar difficulties in aligning values with the state. However, a more sympathetic reading might claim that in labelling the values as 'British', reference is not being made to their origins, discourses of inclusion/exclusion, nor to their availability in a society, but to an aspiration by a particular community to hold fast to these particular values in an attempt to help citizens negotiate their relationships with one another amidst growing diversity in a security-challenged political landscape. ${ }^{9}$

At least part of the problem here is that the proposed list of FBV derives in the main from a security policy (HM Government, 2015), tasked with preventing terrorism. This then gives little coherence to the appropriateness of the content for its other aim, that of supporting social cohesion, which may require a very different set of values. The concept of social cohesion is regarded, even by researchers in this area, as being highly contested and multidimensional in usage (see for example Jenson 2010, Green, Janmaat and Cheng 2011). In other words, there is no consensus among theorists as to what kind of communities are most conducive to social cohesion, nor as to which values need to be shared to support this. But this should not lead one to suppose that philosophers and empirical researchers have completely neglected this area: a rapidly growing literature consistently identifies particular elements as playing key roles: tolerance, respect for others, trust (both interpersonal and institutional), solidarity, loyalty, dignity, fairness, fair equality of opportunity etc (Stevens 2001, Green, Preston et al. 2006, Osler 2011, Starkey 2015). Whilst there is obviously some overlap between both sets of values, it does raise serious misgivings as to how the FBV could possibly support social cohesion using the present restricted set of values. 


\section{ACTIVELY PROMOTING FUNDAMENTAL BRITISH VALUES}

When the need for theory is abandoned, clarity can be lost over ultimate aims; this in turn may lead to misidentifying the values needed for the venture. To address this, the role of promoting policy needs first to be considered. Promotions are everywhere every day: the leaflets in the doctor's surgery promoting health policies; the billboards promoting new products available to buy; the television/media adverts; the offers in supermarkets etc. Promoting policies in such terms not only emphasise the availability of the object but leave it open for individuals to choose to engage if they wish - but there is no obligation for them to do so.

When it comes to enacting promoting policies in schools, this can be placed on a values continuum in three ways: a minimal, a mid-way point and a maximal. First, promotions can simply drawing attention to the values. This seems a relatively noncontroversial practice for schools, who are long accustomed to raising awareness of issues subject to governmental initiatives: posters on healthy eating; classroom book displays on particular topics; the stories read. It could be achieved by having materials available that children could choose to look at or be influenced by (activities of a minimal level of engagement might be wall posters, relevant toys or books or even a series of lessons considering a variety of possible viewpoints) - but the key point is that the school remains neutral between the options. This seems to encourage a knowledge or awareness of the values without overly insisting on their adoption or interpretation (a minimal promotion).

Secondly, promotions can support or encourage a particular choice (a mid-way point). The emphasis here would be on encouraging a form of respect for the values: acceptance of their legitimate existence but hoping that they will be adopted; this might still allow space for a limited dissent or disagreement over interpretation. All forms of values education entail the 
hope that some may choose to adopt such values, while acknowledging that some may choose not to do so. But this goes beyond stating values and leaving it up to individuals as to whether or not to accept these, and has implications for the formation of future citizens of a particular kind: helping children to negotiate the complexities of modern life, which may entail exploration, discussion and critique. This approach is likely to be accompanied by a national citizenship programme of study, possibly including a locally agreed syllabus (as is frequently the case with RE).

Thirdly, promotions can raise something to a higher position than other possible values: 'these values are better than those' (a maximal promotion). This goes beyond just creating 'awareness' (minimal level) or encouraging 'respect' (mid-point) to imply a deliberate attempt to change behaviours/views. It is this possible interpretation that seems to have attracted the most public ire - some communities view the policy as misrecognising them, perceiving by default that some are resistant to 'Britishness' or British Values, or that the values they hold are somehow inferior or inadequate to 'belong' here.

These arguments over the level of promotion might seem at first to be relatively trivial, but they are crucial for understanding the changes in citizenship education in England over the past few decades as evidenced by the shifting language in policy-making itself. The impetus has changed from awareness of common values, to respecting differences and values, to insisting that citizens self-identify and commit to the group values - as shown in the advice to schools on the need to 'challenge opinions or behaviours in school that are contrary to fundamental British values' (DfE Nov 2014: 5). So the problem would seem to be that a minimalist (or thin) interpretations of public values runs the risk of not sufficiently nurturing the affiliative attachments and commitments outside of small groups (including the norms of trust) needed for cohesion; conversely, a maximalist (or thick) interpretations runs the risk of failing to respect the autonomy of individual choosers and of being hostile to legitimate 
diversity. The concern then is that 'policy-creep' has moved the thinking from a 'thin' interpretation of public values to a 'thick' interpretation, without the necessary public debate. Finding a solution acceptable to all, avoiding unconsciously promoting either a minimalist or maximalist policy, requires a far greater clarity over the aims and goals right from the start.

\section{Conclusion}

Given that the self-declared end-goal of the FBV directive is to engender social cohesion (and thus prevent terrorism), the claims that this is a possibility have to be taken seriously. First, how the relationship needed for cohesion comes to be understood is crucial and it is here that the concept of 'perceived belonging' reminds us that who-I-am needs to be (at least) partially constructed with others. A useful metaphor here is that of story-telling: we are all 'storytellers'. But self-narratives are never purely singular: and the focal point of the most important stories in a society tends to be relationship-based: our self with others. Each story connects with the other, enabling development of shared stories. To place this briefly in the language of relationships: the stories we tell ourselves about who we are, are important in how we understand our connectivity; so too are the stories that others tell about us. Without a clear picture of how we should 'belong together', the values and dispositions needed to support this bond cannot be fully identified, running the risk of seemingly random choices.

Secondly, citizens in a socially cohesive society need to have concern for the public way of relating to each other and this in turn requires particular models of civic relationships. Schools play a significant role in this by enabling wider social interactions encouraging the reduction of the distance between citizens and enabling an image of such lives as somehow 'lived together' to emerge. Nevertheless, these models are seldom completely neutral in their commitments and need to cohere in some way with the underpinning values of the society as a whole. The danger is, however, that to accomplish this, some ways of thinking encourage 
the adoption of overly simplistic models for complex aspects of life - and this is the overriding problem with this directive. Without appropriate theoretical involvement, it is left untethered to wider schema.

Finally, it is important to note that none of this is an argument against public values or the need to address extremism/terrorism: the problem lies in how appropriate policy to address such issues is formulated. 'Actively promoting British values' may make a popular political sound-bite, but it clearly needs more theoretical engagement to adequately bear the weight of expectations. Fostering a wide-spread sense of belonging to the polity and a sense of solidarity with fellow citizens is both complex and complicated. This suggests that the formulation of an implementable policy to address issues of social cohesion in the UK may still be somewhat of a chimera.

\section{NOTES:}

${ }^{1}$ The threatened break-up of the UK union by the nationalist parties in Scotland and Wales; the calls for independence in parts of Spain and in the Veneto region in Italy etc.

2 Ofsted inspectors were called in to inspect a number of schools in Birmingham in 2014 after concerns were raised that some governors were having inappropriate influence over the ethos and curriculum of their schools, leaving children 'at risk' of extremism.

3 See http://www.dailymail.co.uk/debate/article-2658171/DAVID-CAMERON-British-values-arentoptional-theyre-vital-Thats-I-promote-EVERY-school-As-row-rages-Trojan-Horse-takeoverclassrooms-Prime-Minister-delivers-uncompromising-pledge.html (last accessed 15.01.2018)

${ }^{4}$ The origins of the policy itself can be traced further back to the increased securitisation concerns of the state post 'Cold War' as well as more familiar responses to the Oldham riots of 2001, terrorist attacks in London in 2005 and the so-called 'Trojan horse affair' of 2013-2014.

${ }^{5}$ See The Daily Telegraph: http://www.telegraph.co.uk/education/2017/06/23/ofsted-will-crackdownextremism-promote-british-values-amanda/ 23.6.2017 reported by Harry Yorke. The talk in question listed a number of other areas that could contribute: SMSC; 'a sense of patriotism'; a 'real civic education'.

${ }^{6}$ In late November 2014, it was reported that there had been 35 'no notice' inspections by Ofsted under the new rules, including 11 that were deemed to be not 'preparing pupils for life in modern Britain': see http://www.telegraph.co.uk/education/educationnews/11253436/Ofsted-rural-schoolsfailing-to-promote-British-values.html for details (25th November: journalists - Graeme Paton and Melanie Hall). Also see: https://www.gov.uk/government/uploads/system/uploads/attachment_data/file/415115/Advice_not e on academies and maintained_schools_Birmingham toSoS_Education.pdf (accessed 10.11.2017)

${ }^{7}$ This is particularly the case in some elements of the right wing press in the UK that emphasise 'desert' rather than 'need' in relationship to the support given to migrants and/or refugees, arguing 
that the former should not have access to welfare support from the state for a period of time to reestablish the link between contributions and shared welfare goods.

${ }^{8}$ For example, the requirement to wear a helmet on a motorbike in the UK, which was adapted to take account of the religious requirement for Sikhs to wear a turban.

9 There have been a multitude of previous attempts by politicians to identify or critique what Britishness means and the subsequent deliberation of what the values binding us together might be: John Major (1993), Tony Blair (2002), Gordon Brown (2004) to name but a few.

References

Antonsich, M. (2009). On territory, the nation-state and the crisis of the hyphen. Progress in Human Geography, 33(6), 789-806.

Antonsich, M. (2010). Searching for belonging - an analytical framework. Geography Compass 4(6), 644-659.

Arthur, J. (2015). Extremism and Neo-Liberal Education Policy: A Contextual Critique of the Trojan Horse Affair in Birmingham Schools. British Journal of Educational Studies, 63(3), 311-328.

Bachtler, J. and C. Mendez (2016). EU Cohesion Policy and European integration: The dynamics of EU budget and regional policy reform. London, Routledge.

Barry, B. (1983). Self-Government Revisited. In: D. Miller. \& L. Siedentop (eds.) The Nature of Political Theory, (Oxford, Oxford University Press).

Baumeister, R. F. and M. R. Leary (1995). The need to belong: Desire for interpersonal attachments as a fundamental human motivation. Psychological Bulletin, 117(3), 497-529.

Buonfino, A. and L. Thomson (2007). Belonging in contemporary Britain. London, Commission on Integration and Cohesion.

Busher, J., T. Choudhury, P. Thomas and G. Harris (2017). What the Prevent duty means for schools and colleges in England: An analysis of educationalists' experiences. Research Report. Aziz Foundation., Durham University, University of Huddersfield and Coventry University.

Cantle, T. (2001). Community cohesion: a report of the independent review team, London, Home Office.

Christiansen, F. and U. R. Hedetoft, Eds. (2004). The Politics of Multiple Belonging: Nationalism and Ethnicity in Europe and East Asia, London, Ashgate.

Clark, J. (2009). Nation-state belonging among Asian Australians and the question of transnationalism. Current Sociology, 57(1), 27-46.

DCSF (2007). Guidance on the duty to promote community cohesion, Nottingham, DfCSF Publications.

DfE (2012). Teachers' Standards, London, HMSO.

DfE (2014). Guidance on promoting British values in schools, London, Crown Publications. DfE (2015a). Personal, social, health and economic (PSHE) education: a review of impact and effective practice, Crown, London.

DfE (2015b). Protecting children from radicalisation: the prevent duty, London, DfE.

DfE (Nov 2014). Promoting fundamental British values as part of SMSC in schools: Departmental advice for maintained schools, London, DfE.

Dobbernack, J. (2010). 'Things fall apart': social imaginaries and the politics of cohesion. Critical Policy Studies, 4(2), 146-163.

Gereluk, D. (2008). Symbolic clothing in schools, London, Continuum International Publishing Group.

Green, A., J. Preston and J. Germen Janmaat (2006). Education, equality and social cohesion, Basingstoke, Palgrave.

Green, A., Janmaat, G. \& Cheng, H. 2011. Social cohesion: converging and diverging trends.

National Institute Economic Review, 215, R6-R22.

Guibernau, M. (2013). Belonging: solidarity and division in modern societies. Cambridge, Polity.

Hand, M. (2011). Patriotism in schools. Salisbury, Wiley-Blackwell/PESGB.

Healy, M. (2013). Philosophical perspectives on social cohesion. London: Bloomsbury. 
HM Government (2015). Prevent Duty Guidance: For England and Wales [online]. https:/www.gov.uk/government/uploads/system/uploads/attachment_data/file/445977/3799_Revised Prevent_Duty_Guidance_England_Wales_V2-Interactive.pdf. Honneth, A. and A. Margalit (2001). Recognition: Part 11. Proceedings of the Aristotelian society, supplementary volumes, $\mathbf{7 5}, 111-139$. Honohan, I. (2008). Metaphors of solidarity. Political language and metaphor: interpreting and changing the world. T. Carver and J. Pikalo (Eds). New York, Routledge, 69-82.

Hooghe, L. (1996) Cohesion Policy and European Integration: Building Multi-Level Governance. Oxford, Oxford University Press.

Jayaweera, H. and T. Choudhary (2008). Immigration, faith and cohesion: evidence from local areas with significant Muslim populations, Joseph Rowntree Foundation.

Jenson, J. (2010). Defining and measuring social cohesion, London, Commonwealth Secretariat and United Nations Research Institute for Social Development.

Keller, S. (2015). The Case Against Patriotism. The Ethics of Patriotism. J. Kleinig, S. Keller and I. Primoratz (Eds). Oxford, Wiley Blackwell.

Kundnani, A. (2012). Multiculturalism and its discontents: Left, Right and liberal. European Journal of Cultural Studies, 15(2), 155-166.

Kundnani, A. (2012). Radicalisation: the journey of a concept. Race \& Class, 54(2), 3-25. Lander, V. (2016). Introduction to fundamental British values. Journal of Education for Teaching, 42(3), 274-279.

Lentin, A. (2014). Post-race, post politics: the paradoxical rise of culture after multiculturalism. Ethnic and Racial Studies, 37(8), 1268-1285.

Leydet, D. (2006). The ideas of 1789 or solidarity unbound: a sceptical appraisal. Philosophy and Social Criticism, 32(7), 799-807.

Mason, A. (2000). Community, solidarity and belonging. Cambridge, Cambridge University Press. May, V. (2011). Self, belonging and social change. Sociology, 45(3), 363-378.

Merry, M. (2009). Patriotism, History and the Legitimate Aims of American Education. Educational Philosophy and Theory, 41(4), 378-398.

Miller, D. (1998). Socialism and toleration. Justifying Toleration: Conceptual and Hisorical Perspectives. S. Mendus (Ed), Cambridge, Cambridge University Press, 237-254.

Mokrosinska, D. (2012). Rethinking political obligation: moral principles, communal ties and citizenship. Basingstoke, Palgrave Macmillan.

Nussbaum, M. C. (1996). For love of country: debating the limits of patriotism / Martha C. Nussbaum with respondents, Joshua Cohen (Ed), Boston, Beacon Press.

Ofsted (2015). School Inspection Handbook: Handbook for inspecting schools in England under section 5 of the Education Act 2005. London, Crown.

Osler, A. (2009). Patriotism, multiculturalism and belonging: political discourse and the teaching of history, Educational Review, 61(1), 85-100.

Osler, A. (2011). Teacher interpretations of citizenship education: national identity, cosmopolitan ideals, and political realities, Journal of Curriculum Studies, 43(1), 1-24.

Panjwani, F. (2016). Towards an overlapping consensus: Muslim teachers' views on fundamental British values. Journal of Education for Teaching, 42(3), 329-340.

Press Association (2015). Teachers 'fear having to report pupils' for expressing views about extremism. The Guardian.

Probyn, E. (1996). Outside belongings, New York, Routledge.

Richardson, R. (2015). British values and British identity: Muddles, mixtures, and ways ahead.

London Review of Education, 13(2), 37-48.

Sieckelinck, S., F. Kaulingfreks and M. De Winter (2015). Neither Villains Nor Victims: Towards an Educational Perspective on Radicalisation. British Journal of Educational Studies, 63(3), 329-343. Smith, H. J. (2016). Britishness as racist nativism: a case of the unnamed 'other'. Journal of Education for Teaching, 42(3), 298-313.

Starkey, H. (2015). Learning to live together: struggles for citizenship and human rights education: An inaugural professorial lecture. London, UCL-IOE Press. 
Stevens, D. (2001). Education, fraternity, and social cohesion: a liberal argument about civic values. $\mathrm{PhD}$, University of Nottingham.

Taylor, C. (1989). Sources of the self: The making of the modern identity. Cambridge, Cambridge University Press.

Vasta, E. (2013). Do we need social cohesion in the 21st century? Multiple languages of belonging in the metropolis. Journal of intercultural studies, 34(2), 196-213.

Wilner, A. S. and C.-J. Dubouloz (2010). Homegrown terrorism and transformative learning: an interdisciplinary approach to understanding radicalization. Global Change, Peace \& Security 22(1), 33-51.

Yuval-Davis, N. (2006). Belonging and the politics of belonging. Patterns of prejudice, 40(3), 197214.

Yuval-Davis, N., F. Anthias and E. Kofman (2005). Secure borders and safe haven and the gendered politics of belonging: Beyond social cohesion. Ethnics and Racial Studies, 28(3), 513-535. 